\title{
Atopic City: Consumption and Death in Urban Life
}

\author{
Rogerio Proenca Leite \\ Laboratório de Estudos Urbanos e Culturais, Federal University of Sergipe (UFS), São Cristóvão, Brasil \\ Email: rproleite@gmail.com
}

How to cite this paper: Leite, R. P. (2016). Atopic City: Consumption and Death in Urban Life. Current Urban Studies, 4, 280-296. http://dx.doi.org/10.4236/cus.2016.43019

Received: July 21, 2016

Accepted: August 19, 2016

Published: August 22, 2016

Copyright $\odot 2016$ by author and Scientific Research Publishing Inc. This work is licensed under the Creative Commons Attribution International License (CC BY 4.0).

http://creativecommons.org/licenses/by/4.0/

\begin{abstract}
This article explores the contemporary dimensions of consumer practices in urban life, specifically in their interrelations with gentrification processes and the development of smart cities. Based on the exploratory concept of Hyperflow positive Ambients, the article looks to comprehend the resonances of the transformation of cities in extended spaces of Consumer Society and the metamorphosis of being into valuebeing. It argues that excessive consumption and the hyperneurotic flow of accelerated capital income is a fatal form of denying the finitude of being and the possibility of death, which connects contemporary corporate urbanism to the consummation of the city and urban life.
\end{abstract}

\section{Keywords}

Consumerism, Urban Life, Gentrification, Smart City

\section{Introduction ${ }^{1}$}

The spread of consumerism and the transformation of being into value-being, combined with the increasing transformation of things into commodities, has turned contemporary society into the most striking expression of Consumer Society, characterized above all by excess, the banalization of life, disposability, human expulsion and the violent obscenity of exchange.

Ever since Nietzsche, Marx, Simmel, Weber and Heidegger, this reified dimension of exchange relations has occupied a prominent place in sociological theory. Simmel (2011), a key author for contemporary urban studies, had already discussed this topic in The Philosophy of Money (2011) and in his critique of modern culture as one of the

${ }^{1}$ This text forms part of the research project Cidade Atópica: ensaios sob a consumaçãourbana [Atopic City: essays on urban consumption], the outcome of a Senior Postdoctorate in Sociology, undertaken in 2014/2015 at the Centre of Social Studies and Economics Faculty of the University of Coimbra, Portugal, with a CAPES research award (Proc. 1892/14-2), Ministry of Education, Brazil. All the research data that supports this article are the result of research conducted by the author and can be accessed freely without trestriction. 
main aspects of modernity, the subject of hard-hitting nihilistic critiques by Nietzsche and Heidegger concerning modern rationality. The idea of a general equivalence of values, however, as Frédéric Vandenberghe emphasizes in his analysis of Simmel's work, conferred more than a mere operationality to exchange: it flattened subjects and objects onto similar levels:

In exchange everything happens as if the subject's fundamental relation to the object, which is a condition of value, in effect goes through objects to allow them to measure each other (Vandenberghe, 2012: p. 227).

Consumer Society is, therefore, the most incisive expression of contemporary society, and one of its main characteristics is excess. Excessive consumption is a form of consummation of urban life. Excessive attitudes in production and consumption are the indelible mark of a class society radically disguised as a socially and politically democratic society. Excessive work, wasted lives, wars, environments saturated with people and rubbish. An excess that sometimes collides with the brutal scarcity of natural resources and over-produced goods with the unequal political economy of excess.

\section{Cities and Consumption}

The principal feature of modern society is not just human alienation through production: it is alienation violently amplified by the market, nourished by excessive, pointless and disposable work and by the accelerated yield of production, which generates services, ideas and goods in excess for financial, market or symbolic exchange. The surplus and excessive work that leads to the most dynamic forms of contemporary surplus value also generates this excess value that feeds back into the production of exchange values at a large scale. And it is precisely in the city that everything pours in the most visible and immediate form:

The city is the geometric place of the spiralling and differential "chain reaction," which sanctions the complete dictatorship of money. [...]. Human density in itself is fascinating, but the discourse of the city is competition itself: mobile, desires, stimuli, the incessant verdict of others, the incessant eroticization, information, publicity requests-all of this forms a kind of abstract destiny of collective participation on the real background of generalized competition (Han, 2014a: p. 73).

The fascination of the city that condenses consumable needs is matched by its practical utility for conducting excessive work, which only became viable with the machinic and mechanical control of the human body, adjusted in muscles and brains to the non-stop management of the For dist production lines. The model of mechanized, repetitive and monotonous work depended, in turn, on complex, highly regulated and rational normative adjustments. Excess is thus a direct descendent of an idea of "productive life" as success or prosperity, measured by the number of things (many completely useless) accumulated during one's life. Some of these things are unattainable for the average incomes of down-to-earth workers, who only with a fair degree of cynicism could be said to be able to possess them. In order for us to accept the high level of re- 
petitive patterns of conduct for executing work in general, we also need to base our analysis on a rigorous conception of reason as a social constraint that is the depositary of a comprehension of work taken to an extreme, resulting in a burnout society (Han, 2014b).

The cities possible in this scenario are very different from the paradisiacal tourist resorts of the upper classes, advertised by global tourist agencies as consumer products supposedly accessible to everyone. No beaches with crystal blue waters exist in the real cities of work and the obscene transparency of consumption. The everyday pace of life is a mechanized march of certain strides. The air is intense, continuous, suffocating. People are forever rushed, their minds set on their immediate goals and the future before them somewhat uncertain, but without anyone daring to doubt it. Few are tolerant of those who hinder the smooth flow of traffic, time, work and life, which needs to flow like a hallucinating spiral in order to fill in the emptiness of the recurrent frustrations and constantly altered aims as though life were a hundred metre sprint. The urban configuration of this reality can be called an Atopic City, immersed in global exchange relations and constituted as a productive post-industrial nucleus.

Atopic is a city situation. A city rendered obscene by the positive flow of capital and the excessive pornographic visibility that exposes everything as value, while subsuming the singularities of the urban topoi and denying the negative tensions of the everyday life that makes it human. In the Atopic City, the other, the one differentiated from the Self, is, at root, a nuisance. Others annoy us either because they confront us with their simple and unbearable happiness or, simply because they get in our way and "disturb and delay the smooth communication of the equal" (Han, 2014a: p. 12).

Just as Consumer Society is the typical expression of contemporary society, the Atopic City is the most incisive, violent and excessive manifestation of Consumer Society. As Byung-Chul Han emphasizes, the logic of consumption became founded precisely on the search for happiness as an equivalent to salvation (2014a, p. 49). Baudrillard's critical analysis highlights a central aspect of the problematics of consumption under modernity: in the modern project, happiness embodies the myth of equality. In consumer society, however, this equality needs to be measurable so that well-being can be observed above all through the consumption of objects. Baudrillard thus denounces one of the fallacies of modernity as a political project: by being incapable of implanting the democratic principle of equality, the modern project grounds a superficial equality in consumption, since it proved incapable of ever achieving the promised real equality:

The democratic principle is then transferred from a real equality of capacities, of responsibilities, of social chances and of happiness (in the full sense of the term) to an equality before the Object and other manifest signs of social success and happiness (2014, p. 50).

In consumer society, where being is transformed into value, the only "equality" left to us is the hell of equals, signalled by the excessive presence of power asymmetries and economic inequalities. As Featherstone (1995) points out, so-called "consumer culture" refers precisely to a wider structural logic within society based around the principle of 
exchange. Bauman (2008) also examines the more extreme form of consumption involving the transformation of people themselves into merchandise, a situation in which exchange comes to model social relations. A reworking of Lévi-Strauss's classic proposition, "consumption is good to think," may well have guided some of the more contemporary reflections on the social meanings of consumption, including Canclini analyses when he looks to apprehend the political and cultural dimension of consumer practices and understand the market not just as a place of exchange, but as a social space "of more complex sociocultural interactions" (Canclini, 1986: p. 66).

However, there are at least two analytic positions that seem to take opposite stances on the relation between consumption and differentiation. On this point, we can pick out not only the economic dimension of exchange properly speaking-relating to the appropriation of goods and defined by the financial possibilities for accessing the products and services available on the market-but above all the cultural meanings of the symbolic act of consuming particular goods, as a social practice that differentiates tastes and life-styles. Pursuing a similar approach to Bourdieu (2008), Mike Featherstone stresses: "If it is possible to claim the operation of a "capital logic" deriving from production, it may also be possible to claim a "consumption logic" which points to the socially structured ways in which goods are used to demarcate social relationships" (Featherstone, 1995: p. 35).

The question is controversial and refers us to the debate on classic polarities in the social sciences. In his analysis of habitus, Bourdieu argues that consumption is a form of social distinction associated with certain social predispositions towards conduct. This approach is consistent with the structuralist interpretation and presents the same limitations to the concept of habitus itself ${ }^{2}$. Baudrillard (1981) offers a different and perhaps more decisive interpretation. Although he sets out from the same understanding of the symbolic nature of consumption, for him the logic involved in the exchange of signs aims to produces ingularities. Although the author exacerbates the idea of the meaning of consumption practices, he emphasizes the symbolic dimension of consumption, which allows the concept to be adapted beyond a purely economic mechanism. Baudrillard writes: "Even before survival has been assured. every group or individual experiences a vital pressure to produce themselves meaningfully in a system of exchange and relationships. Concurrently with the production of goods, there is a push to elaborate significations, meaning-with the result that the one-for-the-other exists before the one and the other exist for themselves" (Baudrillard, 1981: p. 74).

Yet in contrast to Bourdieu, Baudrillarddoes not identify symbolic consumption as the cause of processes of social differentiation. Instead heargues that, although it can reinforce distinctions, consumption operates much more in shaping rather than distinguishing:

It has to be recognized that consumption is not ordered around an individual with his personal needs, which are then subsequently indexed, according to demands of prestige or conformity, to a group context. There is, first, a structural logic of differentiation, which produces individuals as personalized, that is to say, as different

${ }^{2}$ For a more detailed critique of Bourdieu's schema, see Leite, $2010 \mathrm{~b}$. 
one from another, but in terms of general models and a code, to which, in the very act of particularizing themselves, they conform (Baudrillard, 2014: p. 111).

Hence consumption only structures distinctions at a superficial level insofar as differentiations are not reducible to the dispositions of social prestige, all the more so in a society strongly marked by the levelling of being-as-value. Naturally, asymmetric forms of values persist, including the cultural values attached to commodities. Along these lines, Appadurai (1986) points out that symbolic exchanges do not always involve an equivalence of values and equal meanings between the parties as economic exchanges presume. "Regimes of value," as the author defines them, depend on the specificities of the contextual and cultural meanings of exchange:

The variety of such contexts, within and across societies, provides the link between the social environment of commodity and its temporal and symbolic state (Appadurai, 1986: p. 15).

The question of the contexts of exchange and the asymmetrical relations of value relativize the causal influence that consumption can have on social differentiation. In the opposite direction, we can consider, along with Baudrillard, that rather than dividing and differentiating people, acts of consumption have become more and more equivalent to each other in terms of superficial consumption and their maintenance and social conformity as potential consumers. In other words, although consumption can add symbolic values to our existence, we continue to be an equal in the "hell" (Han, 2014a) of inequalities of value-being (Heidegger, 2012).

Consumer Society frequently announces itself in urban life through the excess that, in almost all situations, results in the exacerbation of a certain effort to be in life. An effort that sometimes saturates routines through repetitive engagement in everyday tasks. An excess that leads to burnout, but not only. One of the modern excesses that affect urban life is an alleged clarity over things. Clarity in the literal and metaphorical sense. One of the first excesses to which modern society aspired was the excess of light. Modernity based itself on the idea of an Enlightenment reason capable of freeing everyone, and the iconic city of this philosophy was Haussmann's Paris: reformed, watched, socially hygienic, politically curbed. The City of Light. Of the Belle Époque and public strolls, window displays and cafés. Perhaps the first great "flagship city" of modern corporate urbanism and the stage for a kind of protogentrification (Smith 1996), anticipating many aspects that would go on to constitute contemporary experiences of urban revitalization.

One of the main purposes of the current processes of urban revitalization, especially those involving gentrification (Hamnett, 2000; Atkinson, 2005; Less, 2008), remains the same: to politically and socially sanitize urban space with the control of uses and the insertion of the city in the intense flow of capital. In other words: make the city smooth, unimpeded by negativities (Han, 2014a) that create specific places ${ }^{3}$ that "hinder" the circularity of hypervisible life.

${ }^{3}$ Places that should be understood as sociospatial demarcations of difference, as singularities that demarcate contexts of action and symbolically convergent spaces (Leite, 2007). 
Revitalization processes are implemented above all in areas labelled as "abandoned", "degraded", "inhospitable". Zones of historical areas of cities that are undesired but have a high heritage value. The idea of removing obstacles or barriers to the free flow of consumption, shaped by the specific lifestyle of the middle and upper classes is at the core of gentrification projects. Everything that is or seems to be an obstruction to urban sterilization must be removed. The aesthetic and political intent of urban planning processes introduced to rehabilitate urban spaces is to create an idealized public space: without shadows, ruts, roughness or strangers. A gentrified space must be transparent and literally clear, tidy and luminous (Leite, 2015). Just like the scenario of wide spread consumption practices, it must beclear, well lit, hyperexposed, full of obscene visual stimuli and positivities (Han, 2014a) aimed towards consumption. Gentrified space is a space of excess in which negative barriers are shunned. Every negative opposition to the delirious positivity of consumption and political alienation must be eliminated.

Negativity in the form of an obstacle or transition constitutes negative tension.

The coercion of transparency undoes all thresholds. It is when space is levelled, smoothed and deinteriorized that it becomes transparent. Transparent space is semantically poor (Han, 2014b: p. 50).

\section{Hyperflow Positive Ambients}

Just as the protogentrification of the Parisian Belle Époque served to dampen the negative tensions of the workers' barricades, contemporary gentrification processes gained momentum in the USA as an urban planning and political instrument to calm the negative tension of urban spaces following the assassination of Martin Luther King. Since then, it has transformed into a powerful and effective tool of city marketing that engulfs urban policies worldwide.

It was in Baltimore that the violent repercussion of Luther King's death culminated in the ingenious process of "regenerating" residential neighbourhoods. Left feeling insecure by the negative tension provoked in the city by the demonstrators, residents from traditional districts gave their backing to a set of sanitizing measures that transformed neighbourhoods into clusters that were kept under close surveillance, well-lit and assisted by the State. This was the city's first revenge after the harsh massacres and the confrontation of the demonstrators by the US national guard and army (Harvey, 1992; Smith, 1996).

Reducing negative tension in gentrified spaces involves the annihilation of the innumerable negativities present before and during the urban and architectural interventions. One of the ways of recognizing this reduction is through the aesthetic and functional exacerbation of the spaces. Put otherwise: a gentrified area is recognizable through its excesses. Excessive lighting is one of them. Against the twilight of the areas considered marginal, poorly inhabited and run down a broad spectrum of lights explodes, which function like spotlights illuminating the gentrified urban spaces, increasing the sensation of a set for an urban show where the consumption of places is the main attraction. The lights do not just have the function of physically brightening 
space. They also work to instil the idea of security and cleanness. The excess of light acts as a social anti-septic that dissipates shadows and their undesired correlated uses of spaces. Light sanitizes and, as a result, its use is widely exploited in urban gentrification processes. Excessive light is a form of social constraint, control and surveillance: it prevents the circulation of those excluded from the consumer public of gentrified spaces while simultaneously fostering the hypervisibility of the self-exposure of consumer practices.

The light that sanitizes is equally the clarity that segregates ${ }^{4}$. Light in excess expels the negativities of spaces and reinforces the state of surveillance of the gentrified city. Although almost always based on the rhetoric of "revitalizing" public space, gentrification projects only select areas for consumption, compounding actions that work to segregate. Metaphorically the excess luminosity reinforces the rational idea of a normative deontological order. The light that illuminates the gentrified setting appears as the materialized rationality of entrepreneurial urbanism, grounded in the modern project. Adapting the analysis to the terms proposed by Byung-Chul Han, gentrified space also desires transparency in order to increase the regulatory efficiency of the intended control patterns.

The excessive exposure of things and people is an inescapable feature of contemporary urban life. The old frontiers between public and private dimensions of personal life were subverted long ago by the erosion of the public meaning of urban life itself and by the meanings attributed to private conviviality. Exposing oneself publicly is not necessarily a form of intelligible communicability about what we think and what we wish to express about the world. Exposing oneself has become a mere exhibitionist mirror of ourselves or what we want others to think of us. We are no longer constructed through a dialogical relation with the strange other, but only on by what we ourselves affirm, while our egos are caressed by the proximate acquaintance. Communicability with the alter is not desired, only the excessive exhibition of and for the ego. Concrete or virtual hypervisibility is a highly saturated expression of the excess of smooth and illuminated environments. Twilight is doubt and ambiguity. Imprecision is the enemy of the clarity that accommodates everything in the world of excesses.

Excess luminosity and cleanness function as a form of exp urging urban spaces of everything deemed useless, inadequate and inconvenient. As well as the physical cleanness of pavements, streets, squares and monuments, the society of excess regulates the gentrified city through the cleanness that acts as a form of "social curettage" (Certeau, 1996). Clean and well-lit spaces lend themselves to another form of excess that serves to reduce the negative tensions of gentrified spaces. Light, cleanness and hypervisibility undermine the singularities that would otherwise create dissensions in these transparent spaces. Kept under control and surveillance, the singularities are dissipated and give way to aesthetic-political disciplining, translated into the imperative idea of order. The contemporary excess that accentuates the transparency of urban culture also creates the conditions for transforming cities into hyperflowpositiveambients.

${ }^{4}$ This tension between light and shadow in revitalized spaces has already been explored in the study of a district of Recife (see Leite, 2007). 
Obviously not all cities join the world order of the globalized financial economy in the same form and intensity, and many never become part. World or global cities with an international flow of tourists are almost always hyperflowpositivecities. Cities that go through gentrification processes or that focus on cultivating a smart city image are, to a large extent, hyperflow positive urban ambients.

Few gentrified areas manage to maintain extensive tourist activities and consumption of the locality for any length of time (Leite, 2010a, 2013). After the golden phase of the gentrification processes over the last two decades of the twentieth century, some of the cities that experienced this type of urban intervention have entered a period of decline in which those excluded have gradually begun to reoccupy these spaces. The price for this belated "inclusion" is the return almost to the state of abandonment of these heritage areas (Leite \& Peixoto, 2009). Displaying relatively similar crises, these cities display a cooling of public and private investments, a diminution of the flows of tourist visits, the decay of the symbolic centrality experienced previously, among other aspects.

Not by chance, the crisis in the so-called "Barcelona model" has symbolically struck the heart of the city that lent its name, and the gentrified area of the Catalan city has declined substantially. It is true that Barcelona remains one of the world's most visited tourist cities, but the area surrounding the main gentrified calle harbours strong sociocultural tensions, as in the case of La Raval, which increasingly penetrate Las Ramblas, as though looking to challenge it.

Surprisingly, despite this potential exhaustion (Leite, 2010a) of the gentrification model and its proven negative impacts on everyday life, various cities continue to reproduce this type of urban intervention. Some of the known experiences, successful or otherwise, have invested and appear to continue to invest in two aspects: 1) A type of public sociability founded on a lifestyle specially adapted to consumption, as a form of nurturing the market relations that comprise the predominant feature of these gentrification projects; 2) The transformation of these citizens/consumers to fit this new form of being and living with the other, mediated by the ephemeralness of the phatic act involved in the consumption of places.

Both the "investments" evoke the debate on the critique of modern reason and modernity itself. The processes of gentrification could, indeed, be taken as extreme expressions of a declining modern urbanism whose profiting subject-centred on its own reason-became the epicentre of widespread practices of consumption and reification, annihilating itself as a being by transforming itself into a value in the Nietzschean-Heideggerian sense (Vattimo, 2007).

Critiques of gentrification processes should focus their efforts on overcoming a current tendency (possibly exhausted) to point out successes or mistakes from certain points of view, describe and compare actions, or analyse the social and environmental impacts of interventions, especially in historical and environmental protection zones. Instead, they should aim to understand the logic of the enterprise that turns these cities into hyperflowpositive ambients. 
Taking another approach, smart cities (Landry, 2008; Townsend, 2014) seem to attract the main characteristics of hyperflowpositivity. It should be stressed that the most important cities considered smart are also conceptualized as globa $\bar{P}$. However, there are no agreed indices and parameters on what qualifies as a smart city. There is a set of criteria, relatively dispersed, surrounding questions like governance in public administration, mobility, accessibility, connectivity, sustainability, inclusion, creativity, innovation and technology. The idea mobilizes these themes in order to rethink a concept of the city that matches the wider interests of global capitalism. Many world metropolises are included, in different and contradictory positions, in a wide range of different smart city rankings.

In this proliferation of indices, more cities appear than positions in the rankings: London, Singapore, Seoul, Amsterdam, Berlin, Barcelona, Copenhagen, Hong Kong, Seattle, Lisbon, Tokyo, Hamburg, Genova, Oslo, Mannheim, Basel. Depending on the parameter, one or another is selected. Positions change. Each country, for its part, selects its own criteria for inclusion, as well as forming networks of supposedly smart cities. A small Spanish or Portuguese city may be considered smart because it has cycle lanes and green areas, but is unlikely to remain in a prominent place if the criterion is corporate development in the area of digital knowledge. Hong Kong may be considered smart due to its high level of technological production, but may lose the attributeif the criteria is residence or urban mobility. In Portugal, RENER Living Lab ${ }^{6}$ (Portuguese Smart Cities Network) encompasses 43 cities with very distinct and debatable levels of development, just like its Spanish neighbour RECI (Spanish Smart Cities Network).

This conceptual inclusion is very often a sham. The rubber stamp desired to enter the market of institutional recognition opens the doors for financing, investment and generous lines of credit. This coveted inclusion in the system highlights more than the real situation of each city: it reveals the marketing structures that have always surrounded cities and that in the last three decades have become increasingly elaborate. The flexibility in criteria and concepts, manipulated according to diverse interests and strategies, reveal some of the obscenity of this old and renewed logic of gentrifying urbanism. Everyone wants to be creative, smart, intelligent, innovative, technological, entrepreneurial. Cities, once again, are safeguarded for financial speculation, new forms of profit making. What precisely does "this" new entrepreneurial urbanism want?

In Portugal, INTELI ${ }^{7}$ encapsulates the question in setting out the objectives behind the actions of the Cities project:

The production of recommendations for the development of the culture industries, in particular the creative entrepreneurship associated with urban regeneration. The regeneration of rundown districts and old industrial areas has become

\footnotetext{
${ }^{5}$ To discover a city's globality level, see the ranking of the GaWC network at the Department of Geography of Loughborough University, UK.

${ }^{6}$ http://rener.pt/

${ }^{7}$ In its own definition: "INTELI is an Innovation Centre committed to a new model of sustainable economic and social development of the Portuguese economy, based on knowledge and innovation." See: http://www.inteli.pt/pt/go/missao
} 
especially important as a form of promoting, attracting and fixing activities and creative and skilled human resources ${ }^{8}$.

The transparency of this recommendation is doubly obscene: first, because it strategically associates the concept of entrepreneurship with forms of urban "regeneration" in "degraded" areas, and, second, because it argues that this "regeneration" helps attract and fix new "skilled" users. The proposal simultaneously reveals the prejudices concerning the central spaces of cities and their formers residents, poor, homeless, unemployed, an entire range of "inadequates" who live in or occupy these urban areas.

Studies of gentrification experiences in many cities across the world have consistently shown the high level of sociospatial segregation and exclusion involved in the practices that transform high-value heritage sites into attractive spaces for business ${ }^{9}$. The City Marketing of the 1980s is now acquiring, in these first decades of the twenty-first century, more sophisticated profiles and an even more seductive discourse having turned to the idea of a city for people: urbanism entrepreneur. "It's all about people" was the central theme of the International Conference held in October 2014 in Vila Nova de Gaia, Portugal. Naturally the question is knowing "who are these people?"

Barcelona-another "flagshipcity" of the more contemporary experiences of urbanism over the last three decades, the setting for some of the most daring, unusual and also mistaken experiments in urban "revitalization" policies, especially in historical heritage areas-is once again surprising: a globally recognized city (Beta+ Index on the GaWC 2008) ${ }^{10}$ and considered one of the most important smart cities in Europe, has developed for more than a decade a polemical "revitalization" project in the old industrial zone of Poblenou. Through a new law decree, a new designation was created for the area, previously part of industrial sector 22a. Now suggestively called 22@, the project aims to implant new and "smart" buildings and activities with the intention of stimulating services and businesses related to the new knowledge technologies. All of this for "people"? But what about the working class families still living in the Poblenou district? What exactly does the 22@Barcelonaproject mean in the context of entrepreneurial urbanism?

Still on the topic of Spain, we can highlight the city of Bilbao, another "flagshipcity" of the "ultramodern" architectural and urbanist trends and a member of the "smart" cities network of the same entrepreneurial urbanism. The Bilbao Ria 2000 Projecthas adopted the same approaches to intervening in "deteriorated" industrial areas in order to reconvert uses and activities ${ }^{11}$. Bilbao and Barcelona are similar cases and can be taken as paradigmatic of the convergence of the two tendencies emphasized here, combining urban gentrification experiences and smart cities projects. This is why they provide two heuristic cases for the reflection pursued here concerning the positive transparency that seems to have undermined the possibilities for emancipation due to the market exacerbation of modern reason.

${ }^{8}$ See the site of INTELI, the entity responsible for running the RENER Network (Portugal Smart Cities Network), a member of the European Network of Living Labs. http://smartcitiesportugal.net/

${ }^{9}$ On the diverse studies undertaken on European and American cities, see Leite, 2009, 2010a, 2013.

${ }^{10}$ http://www.lboro.ac.uk/gawc/world2008t.html

${ }^{11}$ See Furtado \& Alves 2012. 
What Barcelona and Bilbao almost paradigmatically represent is this convergence of tendencies found in a fashionable global urbanism, synthesized in the association between gentrification and smart cities: aggressive entry into the global market of goods and services connected to international tourism; urban market-centred interventions; gentrification of port and/or historical areas with the aim of "regenerating" their utilization; heritage conservation policies associated with real estate appreciation and speculation; the sanitization of public spaces; strong visual appeal through a monumental architecture; sociospatial segregation of the "renewed" areas due to the rise in the socioeconomic levels of the offered products; and inclusion of the local economy in the global and financial flows of digital and technological capital.

\section{Mere Life and Being-towards-Death}

The order demands excess and it is within this order that the Atopic City maintains the accelerated pace of everything: production, consumption, leisure. The acceleration of the flows of production was, along with the dividing up of the production process, one of the most striking technical revolutions of the modern era. The idea of producing more than necessary in order to enable the expansion of a system of surplus exchange did more than dynamize the incipient manufacturing trade as it emerged during the High Middle Ages. It created an ethos focused on work and the production of goods that affected the human soul in definitive form. Among other aspects, this ethos is strongly marked by the secular idea of optimal time. Weber had already drawn attention to Benjamin Franklin's motto Time is Money, arguing that it had steered part of western rationality towards the maximization of profit. The excess of physico-mental conditioning factors aimed towards increasing productivity has become more sophisticated and changed greatly since the furnaces drove the Taylorist production environments. The full-blown Consumer Society involves what Byung-Chul Han calls a positivization of the world that has radically transformed human nature: "The late modern animal laborans, strictly speaking, is everything but an animal. It is hyperactive and hyperneurotic" (Han, 2014b, p. 34).

For Han, this hyperneurotic and hyperactive being is not just a psychopathological consequence of work, as in the classic form analysed by Dejours (1980): rather, it isa kind of response to the emptiness and ephemeralness of life in contemporary society. This response, however, seems to be merely an adaptation to the demanded levels of profit. It is not a response that opposes, rejects or confront the order of things. The hyperactive being is only a being over-adapted to the flow of production:

Following the aforementioned general positivization of the world, both man and society were transformed into autistic machines of production. We could indeed

say that it is precisely the exaggerated effort to maximize production that suppresses negativity, since the latter delays the process of acceleration. (Han, 2014b: p. 42)

Hyperactivity is a standard form of excess in compulsive modern work. It results in 
two distinct forms of burnout, Byung-Chul Han argues. The first kind of burnout is associated with physical and mental exhaustion. This tiredness derives from the collapse of the person's creative and operational capacity amid the excess of positivity. It is a kind of productive drowning of the person in the hallucinating flow of production and consumption.

Another form of burnout subsists in the altered form of a dissatisfaction with the pace of modern life, in its forms of unattainable aims and expectations always closely adapted to existing patterns of obedience. This burnout is not a collapse, as such, but a form of discontent. In the reflexive line adopted here, being dissatisfied is a form of critical negativity, a form of disobedience that impels being in other directions. Satisfaction with the positivity of the world of consumption entails being reduced to value-being. Put otherwise: the burnout that rescues us from positivity is the same that makes us unadapted to the demands of hyperactivity. Rather than exhausting us, this tiredness revives us by reducing our productive ego and placing us in another temporality in everyday life:

Tiredness as a "greater reduction of the self" opens up space for a between, insofar as it loosens the straitjacket of the Self. I don't only see the other, I am the other too and the other becomes me as well. (Han, 2014b: p. 53)

Burnout as discontent should not considered anathema to the idea of vitality. Rather than preventing action, it dislocates it to other parameters distinct from those related to limitlessproductivity. In this sense, this tiredness is a political confrontation of hyperactivity. And this hyperactivity, in the terms set by Byung-Chul Han's analysis, is an "extremely passive [form] of action that no longer allows just any free activity. It is rooted in a unilateral absolutization of positive potency" (2014b: p. 43). Between exhausted and hyperactive remains an ultimate question concerning the modern meaning of life and the significance that we attribute to time and activities in the everyday world.

The excess that marks contemporary urban life reveals the more superfluous but inescapable dimension of what Byung-Chul Han calls "burnout society." Excess in everything leads us to search ceaselessly for the maximum yield, to a kind of life for life's sake or mere life. More than an exacerbated defence of productive life (because indeed, in this conception, it is not enough to be alive: it is necessary to be a hyperactive subject of yield), what is manifested is the rejection of the natural finiteness of being, converging on the simple idea of death. By prevaricating death, the urban culture of profit and work encounters in mere life a form of opposing all the negativity hindering the flow of production.

The work of the hyperactive subject thus contains a paradox. As Baudrillard (1996) astutely observes, capital exploits people until they die. A slow and inexorable death. In the end, though, it denies them the very right to die. Power expresses itself through the suspension of death. Like the life that the slave lacks, so too his or her death. Contemporary society denies death and, through its accelerated routines, reiterates mere life. Reflecting on the relation between master and slave, Baudrillard (1996) points out that power did not come exactly from the slave being condemned to death but, on the con- 
trary, from death being denied: "The master confiscates the death of the other while retaining the right to risk his own" (Baudrillard, 1996: p. 77). In other words: being able to die is actually recognition of the condition of being alive, living in the finite condition of being.

The high productivity that denies death, rather than signifying emancipation, perhaps comprises the self-imprisonment of being in a positive economic rationality, instrumentally based around the triadic idea of work-production-consumption. The apology for mere life, by denying the emblematic dimension of the finitude of being, also undermines all social practice and modes of life that fail to match the accelerated pace of life.

Positive society, from which the negativity of death has been removed, is a society of mere life, dominated merely by the concern to "ensure the survival of discontinuity." And that is the life of a slave. This concern for mere life, survival, deprives life of all its vivacity, which represents an extremely complex phenomenon. The merely positive is deprived of life. Negativity is essential to vitality. (Han, 2014c: p. 33)

In this line of thinking, a person who does not accept death avoids life for mere life, insofar as he or she does not fully consent to their inevitable finitude. By not recognizing the negativity of existence, such a person does not question, contest or confront. Excessive cities also snub death in their excess of life for consumption and leisure. They disdain death above all because they do not wish to be contested. Gentrified and smart spaces are projected onto urban life as truths supposedly valid for all users (or, at least, for those targeted by these projects), when we actually know that only a few have access to these spaces.

Atopic Cities do not support the asymmetries of contingent life and, just like people in their excesses of active life, do not accept their probable impossibility of being. Thinking the death of being means implies awareness of its finitude, its provisional nature, its singular and transitory existence: "Death is the possibility of the absolute impossibility of Dasein" (Heidegger, 2012: p. 691). Consequently, the impossibility of being is a negativity, insofar as it is associated with non-being, non-doing, non-winning. People and spaces that cannot bear the possibility of failure are like entities of a mere life, deprived of their dynamic conditions of change, given the possibilities of no-longer-being. Hence it is not existence-in-itself or mere life that defines being. What defines it over the course of its temporal existence is precisely the imponderable possibility of one day simply no-longer-being. This strange negativity to life is what Heidegger identifies as the contingent existence of Dasein itself: "Its death is the possibility of no-longer-being-able-to-be-there" (Heidegger, 2012: p. 691).

Hyperflow positive spaces are projected to override the contingencies set by all kinds of obstaclescapable of resisting the consumerist and pacifying dream of the negative tensions of ordinary life. These are spaces that aim to be categorical in the imputability of widespread forms of normative coercion in order to suppress counter-meanings and counter-uses. They do not allow negative, counter-usual presence, the kind that would 
authorize contestation in the form of dissonant uses. In other words, accepting negative presence would be to accept the finitude and mortality of being. But this is denied. And it is denied because death represents the contingency of life and its inescapable finitude. The arrogant positivity of hyperflow positive spaces never consents to interrogation of any inadequacies existing in the course of planning and executing urban projects.

Refusing the possibility of failure to the process and everything that the dynamic and contradictory negativity of life represents means exonerating oneself from having to imagine other paths and possibilities, as though life were just mere life. Death is, therefore, an in dispensable channel for the slow, deep and creative flow of the negativity of life. In this debate, death does not represent the end of being as such, only the condition of always being in the possibility of dying. And if this possibility exists, being experiences its own impossibility. In Heidegger, Dasein ${ }^{12}$ is a being-towards-death precisely because of its contingent existence. Death thus marks out the temporality of Dasein: it is not a stage of life, but a condition of being, as Emmanuel Levinas emphasizes:

Death is not a moment of one's being. It is not a moment, but a manner of being of which Dasein takes charge as soon as it is, such that the expression "to have to be" also signifies “to have to die." (2012, p. 70)

The being that does not contemplate death as a possibility of no-longer-being-ableto-be-there is a subjected being, in the sense of being submersed in the continuous flux of mere life. This subjected being is a passive being adapted to the positivity of Consumer Society. Subjection to continuous work is one expression of this state of being subjected, as Baudrillard stresses:

The scenario has never changed. Whoever works has not been put to death, he is refused this honour. And labour is first of all the sign of being judged worthy only of life. (1996: p. 76).

Without the right to death, the subject of work and yeld is plunged into mere life and the "subject of reason" becomes subjected to the reason of production of consumption. Without death and its wider meaning of finitude and transformation, being surrenders to life as though only it remains. For Baudrillard, the denial of death means imprisonment in life and subservience to the power of capital. This is why he asserts that the alternative to work is not free time but sacrifice. Precisely like Heidegger, the authors Baudrillard and Byung-Chul Han argue that it is not existence-in-itself or mere life that defines being, but its capacity to perceive its own finite existence.

Modern urbanism, the heir of a linear Kantian reason, makes no distinction between users, does not respect differences and refuses to listen to marginal populations: it simply plans interventions and executes them on the basis of the predominant criterion that affirms the supposed universal dimension of consumption in contemporary quotidian life. Urban modernism, the heir to this reason, helps promote the hell of the equal.

The outcome is the transformation of urban spaces and cultural heritage into con-

\footnotetext{
12“The world of Dasein is the world-with" (Heidegger, 2012: p. 345).
} 
sumer products, and citizens transmuted into consumers. Hence, at the lower and circumscribed level of the city, this urbanism repeats the fallacy of the modern project that promised to emancipate and create equality and fraternity among people very distinct from each other. Indeed the only equality that the modern project really enabled was that of reducing everyone-equally-to a value-being.

The denial of the similarity of urban space and its reduction to a generalized logic of consumption has made certain spaces of the city expressions of an accelerating decline in post-gentrified cities. And here perhaps we need to return to the beginning to observe that, despite the exhaustion of the gentrification model and its proven negative impacts on everyday life, various cities continue to reproduce this type of urban intervention, always with an air of renewal and other terminologies. For at least four decades now we have witnessed similar urban intervention processes in sites with a high heritage value going under a variety of names: revitalization, rehabilitation, regeneration, gentrification, creative cities, intelligent cities or smart cities. Conserving the peculiarities of each, these initiatives main points of similarity are their invasive approach to native residents, their overly market-oriented approach to the treatment of existing spaces and heritage, and, in general, and their lack of any decency in the installation of mechanisms that segregate the uses of urban spaces.

Never has the contemporary city had so much need of the negativities that hinder and can perhaps contain the hyperflow positivity in which they are embedded. These negativities exist and always existed in everyday public life. We know why cities exist historically. What we have perhaps forgotten was to ask what is the precise value that cities have for the diverse people inhabiting them. We have perhaps forgotten to see the city as a phenomenal expression that, for this reason, is irreducible to strategic plans that think of it as a unity, as though it were a thing-in-itself.

Cites-especially (but not only) those targeted by the wide-ranging intervention projects of so-called entrepreneurial urbanism-have become an obscene market of things, signs and persons, where everything is up for sale, including the city itself, as a city. insofar as it is transformed into a locus split into consumable heterotopies. Difference has also been turned into a commodity that becomes depoliticized with each passing day, more performance than non-conformity or a point of reference for identities. This excess of everything, of consumption and the hyperneurotic flow of the accelerated production of capital, is a fatal form of contemporary consummation of the city and urban life. The city that has become more city-like-that is, more marked by the elements that confer and inform an urban character-has actually become less of a realcity. In other words: the more a city appears to intensify its urban characteristics, the more it becomes unviable as a city, as a space for living-with-others, to the point that we can call the city a utopia of itself.

Rather than rethinking models, adaptations or new forms of reproducing existing projects of urban intervention, perhaps we should be asking definitively what city we want for the future, for whom and for what purpose. Perhaps this will allow us-who knows, by eluding the excess of normative disciplining-elaborate a new enigma for the 
urban world, founded more on the hope for the future and based on the experience accumulated from the past.

\section{References}

Appadurai, A. (1986). The Social Life of Things: Commodities in Cultural Perspective. Cambridge: University Press. http://dx.doi.org/10.1017/CBO9780511819582

Atkinson, R., \& Bridge, G. (Eds.) (2005). Gentrification in a Global Context: The New Urban Colonialism. London: Routledge.

Baudrillard, J. (1981). Para umacrítica da economiapolítica do signo. Lisboa: Edições 70.

Baudrillard, J. (1996). A TrocaSimbólica e a Morte. Vol. I, Lisboa: Edições 70.

Baudrillard, J. (2014). A Sociedade de Consumo. Lisboa: Edições 70.

Bauman, Z. (2008). Vida para o consumo. Rio de Janeiro: Zahar.

Bourdieu, P. (2008). A Distinção: Crítica Social do Julgamento. São Paulo: Edusp.

Canclini, N. G. (1986). Consumidores e Cidadãos: Conflitosmulticulturais da globalização. Rio de Janeiro: Editora UFRJ.

Certeau, Michel de. (1996), Ainvenção do cotidiano. Petrópolis, Vozes.

Dejours, C. (1980). Travail, usurementale-De la psychopathologie à la psychodynamique du travail. Paris: Bayard Éditions.

Featherstone, M. (1995). Cultura de Consumo e Pós-Modernismo. São Paulo: Studio Nobel.

Hamnett, C. (2000). Gentrification, Postindustrialism, and Industrial Restructuring in Global Cities. In G. Bridge, \& S. Watson (Eds.), A Companion to the City (pp. 331-341). Oxford: Blackwell Publishing.

Han, B.-C. (2014a). A Sociedade da Transparência. Lisboa: Relógio d'Agua Editores.

Han, B.-C. (2014b). A Sociedade do Cansaço. Lisboa: Relógio d'Agua Editores.

Han, B.-C. (2014c). A Agonia de Eros. Lisboa: Relógio D’Água Editores.

Harvey, D. (1992). Condiçãopós-moderna. São Paulo: Loyola.

Heidegger, M. (2012). Ser e Tempo. (Edição bilíngue Português/Alemão, Traduzida e organizadapor Fausto Castilho). Rio de Janeiro: UNICAMP, Vozes.

Landry, C. (2008). The Creative City: A Toolkit for Urban Innovators (2. $\left.{ }^{\mathrm{a}} \mathrm{ed}.\right)$. London: Comedia.

Leite, R. P. (2007). Contra-usos da cidade: Lugares e espaço public na experiência urbana contemporânea (2nd ed.). Campinas: Editora da Unicamp.

Leite, R. P. (2010a). A exaustão das cidades: Antienobrecimento e intervenções urbanas em cidades brasileiras e portuguesas. Revista Brasileira de Ciências Sociais, 72, 73-88. http://dx.doi.org/10.1590/S0102-69092010000100006

Leite, R. P. (2010b). A inversão do cotidiano: Práticas sociais e rupturas na vida urbana contemporânea. Dados, 53, 737-756.

Leite, R. P. (2013). Consuming Heritage: Counter-Uses of the City and Gentrification. Vibrant: Virtual Brazilian Anthropology, 10, 165-189.

Leite, R. P. (2015). Cities and Gentrification in Contemporary Brazil. Current Urban Studies, 3, 175-186. http://dx.doi.org/10.4236/cus.2015.33015

Leite, R. P., \& Peixoto, P. (2009). Políticas urbanas de patrimonialização e contrarrevanchismo: O Recife Antigo e a Zona Histórica da Cidade do Porto. Cadernos Metrópole, 21, 93-104.

Less, L., Slater, T., \& Wyly, E. (2008). Gentrification. Nova York: Routledge. 
Levinas, E. (2012). Deus, a Morte e o Tempo. Lisboa, Edições 70.

Simmel, G. (2011). The Philosophy of Money. London: Routledge.

Smith, N. (1996). The New Urban Frontier: Gentrification and Revanchist City. London: Routledge.

Townsend, A. M. (2014). Smart Cities: Big Data, Civic Hackers, and the Quest for a New Utopia. New York: WW Norton \& Company.

Vandenberghe, F. (2012). Uma Historia Filosófica da Sociologia Alemã: Alienação e Reificação. Vol. 1, São Paulo: Annablume.

Vattimo, G. (2007). O Fim da Modernidade; niilismo e hermenêutica na cultura pós-moderna (2a. ed.). São Paulo: Martins Fontes.

Submit or recommend next manuscript to SCIRP and we will provide best service for you:

Accepting pre-submission inquiries through Email, Facebook, LinkedIn, Twitter, etc. A wide selection of journals (inclusive of 9 subjects, more than 200 journals)

Providing 24-hour high-quality service

User-friendly online submission system

Fair and swift peer-review system

Efficient typesetting and proofreading procedure

Display of the result of downloads and visits, as well as the number of cited articles Maximum dissemination of your research work

Submit your manuscript at: http://papersubmission.scirp.org/ 